\title{
Economic Recession in Nigeria: Implications for Nursing Education and Practice
}

\author{
Abba Kale $(\mathrm{RN})^{1}$, BabajiMaigari ${ }^{2}$, HabuHaruna ${ }^{3}$ \\ ${ }^{I}$ Department of Sociology and Anthropology. University of Maiduguri. Borno State Nigeria \\ ${ }^{2,3}$ Department of Nursing Science.University of Maiduguri.Borno State Nigeria
}

\section{Introduction}

It is no more news that Nigeria is in Economic Recession. What is news, however, is how she comes out of it. The decline in economic activity cuts across every sphere of life, business, technology, industry, education, health etc. It remains pertinent, therefore, for us to examine the consequences of the recession on the citizenry. The implications of this on Nursing Education and Practice would undoubtedly be a topical issue for all thinking nurses. The National Bureau of Economic Research (NBER ) defined a recession as " a significant decline in economic activity spread across the economy, lasting more than a few months, normally visible in a real gross domestic product (GDP), real income, employment, industrial production and wholesale-retail sales.' Economic recession can also be defined as a negative real GDP growth rate for two consecutive quarters (say first and second quarter). Judging by the above definition Nigeria is experiencing economic recession currently, since her first and second quarter growth in 2016 are $-1.7 \%$ and $-2.06 \%$. (Osalor, 2016)

People often say a recession is when the GDP growth rate is negative for two consecutive quarters or more. Nigeria's economic situation is in 'its worst possible time,' according to Finance Minister KemiAdeosun. The inflation rate shrank at $17.1 \%$, the GDP had contracted by $2.06 \%$, the economy by $0.36 \%$. (Osalor, 2016)

How do the nurse and the nursing profession fare; as we are aware nurses form the largest professional group in the health sector in Nigeria? Thus, anything affecting health has its impact on the Nursing profession and its practitioners. In the course of the paper, an attempt will be made to describe economic recession, and other related concepts, its background, causes, general impact, how to stem the tide, impact on health, implications to the nursing profession, the way forward as well as concluding remarks.

\section{Global Perspective}

The global financial crises is been called by leading economist the 'worst financial crisis' since the one related to the great depression of the 1930s. (Reuters). It contributed to the failure of key businesses, declines in consumer wealth estimated in the trillion of US dollars, substantial financial commitment incurred by government, and a significant decline in economic activity (Brookings-financial crisis). Many causes have been proposed, with varying weight assigned by experts. (Bernanke) Both market based and regulatory solution have been implemented or are under consideration (Obama 2009) while significant risks remain for the world economy (Roubini-Do, risks to global growth).

The collapse of a global housing bubble, which peaked in the USA in 2006 caused the values of securities tied to housing prices to plummet thereafter, damaging financial institutions globally (NPR 2009). Questions regarding bank solvency, declines in credit availability, and damage investor confidence had an impact on global stock markets, which suffered large losses during late 2008 and early 2009. Economies worldwide slowed during this period as credit tightened and international trade declined (IMF 2009). Critics argued that credit rating agencies and investors failed to accurately price the risk involved with mortgage-related century financial markets (Declaration of G20 Sept. 2008). Government and central banks responded with unprecedented fiscal stimulus, monetary policy expansion and institution bailouts.

Economic downturns and recession and the global economy have affected people across the world in many ways. Health impacts of these recessional factors are the most severe ones especially in an already stressed health care delivery system like ours. The overwhelming effect of the recession would undoubtedly result in increase rate of malnutrition, anaemia, infant and maternal deaths, communicable and noncommunicable diseases, psychological disorders, social maladaptive behaviours, violence to mention but a few. (Sowunmi, 2009). There is ample evidence that health care delivery systems worldwide were already in shambles before the economic meltdown. For instance, health care expenditure rose from 3\% of world GDP in 1948 to $7.9 \%$ in 1997. Yet the health status of hundreds of millions of people in the world remains unacceptable. In Nigeria, a combination of world economic crisis of the late 1970s and early 1980s led to a fall in the proportion of Federal Allocation to health sector with the result that health needs of Nigerians remains unmet and the morbidity and mortality rates remain high. (Ote, 2009). Consequent upon this, the following impacts is felt globally: 


\section{Impact on Financial Institution}

International Monetary Fund estimated that large US and European banks lost more than 1 trillion on toxic assets and from bad loans from January 2007 to September 2007. These losses were expected to top \$2.8 trillion from 2007-2010. US banks losses were forecast to hit \$1 trillion and European bank losses will reach $\$ 1.6$ trillion. The IMF estimated that US banks were about $60 \%$ through their losses, but British and Euro zone banks only 10 percent.

\section{Impact on Credit Market and Shadow Banking System}

Due to massive withdrawals from money markets corporation were unable to rollover (replace) their own debt. They lost $\$ 7.1$ billion in a week. US government responded by extending insurance for money market accounts, to no avail, a $\$ 700$ billion emergency bailout had to be proposed and Emergency Stabilization Act also called the Troubled Asset Relief Program (TARP) was signed into law.(IMF, 2009)

\section{Wealth Effects}

There is a direct relationship between decline in wealth, and declines in consumption and business investment, which along with government spending represent the economic engine. America lost within one year (2007-2008) more than a quarter of their collective net worth. During the same period saving and investment assets (apart from retirement savings) lost 1.2 billion and pensions assets $\$ 1.3$ trillion. (Norm, 2008)

\section{Effects on the Global Economy}

- Extended recession with very little recurring in 2010

- Fears of global economic collapse

- Is likely to yield the biggest banking shake out since the savings and loan meltdown

- Recovery unlikely for at least 2 years

- Decline in GDP in first quarter of 2009. Germany GDP decline was 14.4\%, Japan 15.2\%, UK 7.4\%, 18\% in Latvia, $9.8 \%$ in Euro area and $21.5 \%$ for Mexico.

- Increased unemployment rate (10.2\%) in October 2009 in US.

\section{How Did Nigeria Get Herself Into Recession?}

Before we explain how Nigeria got herself into recession, let us look at the general causes of economic recession in any given economy.

\section{General Causes of Economic Recession}

The major causes of economic recession in any given economy(lessons from great depressions, 1981, 1991, 2008 economic recession) may include:

- High inflation, a general rise in price of goods and services- leading to low purchasing power.

- Accumulation of debt servicing especially foreign debt.

- High-interest rate- discouraging investors.

- Fall in aggregate demand; fall in wages, income etc.

- Mass unemployment and general loss of confidence on the government (Isheikwere, 2016).

\section{Causes of Economic Recession in Nigeria}

1. Poor economic planning: Poor economic planning and no concrete implementation of her economic planning is the major cause of Nigeria current recession.yes the government has proclaimed the usual generalities that every government indulges itself in about

- Diversifying the economy,

- Improving manufacturing/mining sector,

- Raising agricultural output,

- Encouraging foreign investment, among others, yet no concrete evidenced strategic plan for growth.

No doubt, the government has taken some steps like the elimination of dollar purchase privileges for importers of 40 items such as-rice, cement, toothpicks, private planes, poultry, meat, margarine, wheelbarrows, textiles and soaps. The government has on the other hand, caused serious poverty in the land by her. The government through her policy widen the gap between the rich and the poor-creating more economic hardship.

For instance, when the Central Bank of Nigeria (CBN) was selling dollars at N197 and people were buying at N300, the highly placed individuals in the country were putting call across the banking industry to get dollar at the official rate. This they later resell at the parallel market rate of N300. Think of how much some of them were making. An individual can make as much as N1 billion naira without doing anything according to the former CBN governor (LamidoSanusi). 
The people that were profiting from this were people that were telling the government that if it didn't devalue the naira people would suffer. The poor paid the price of a devalued currency and the rich schemed off the profits. For example, should you take dollars, for every $\$ 1$ billion taken from the Federation Account and sold by the CBN at N200 to the dollar, the states were loosing N100 billion that could have gone into salaries, agriculture, health care!

Yet the states were going to borrow from the same government on a bailout when the government was selling dollars cheaply to a small group of people. This incidence is still ongoing and the government is doing nothing about it.

2. High Inflation Rate: government banning the importation of certain essential agricultural products like rice without considering gestation period is error. Removal of fuel subsidy shouldn't be simultaneously with the banning of these agricultural products. Nigeria inflation rate currently stands at $17 \%$, that is extremely high.

3. High Interest Rate: interest rate is between $26.77-27 \%$. Is extremely high for investors. This high interest rate is discouraging investors. The poor investment culminates into high rate of unemployment in the country.

4. High Taxation: it is only in Nigeria that you see government charging high tax rate during economic recession. Small businesses are slaughtered with high interest rate. Both high interest and tax rate has lowered Nigeria aggregate demand.

5. Policy conflict: the economic policies appear conflicting. How? High-interest rate, high tax rate are tight monetary policy measures. But government told the public it is adopting expansionary policy-budget deficit.

6. Overdependence of the nation on petroleum as a source of income, according to the CBN Governor, Nigeria gets over $95 \%$ of its revenue from oil.

7. Resource mismanagement (not just petroleum, but natural gas as well), countries like Malaysia and Singapore in the 1970s had the same revenue with Nigeria but today make more than 11 times the revenue of Nigeria.

8. Niger-Delta Militant Activities: this factor has worsened the situation as the barrels of crude produced per day have dropped due to militant activities in kidnapping, stopping operations and damage to oil wells.

9. High Rate of Importation: this has been a great menace to the Nigerian economy as many commodities are imported and on the long run other economies benefit from Nigeria. For example, many electronic products are imported from China.

10. The Debt Game: (on all levels): Nigeria as a country is still heavily indebted to the World Bank and International Monetary Fund (IMF).

11. The Changing Dynamics of Over Population has also affected the Nigerian economy because adequate plan have not been put in place for the nation's increasing population.

12. Outright Corporate Greed exhibited by various companies and service providers also have a major contribution to the economic situation in the country.

13. The national relocation of employment and the changing of means of labour also have a part. Many people are migrating to major cities like Lagos, Abuja, Port Harcourt causing these cities to be overpopulated and few people left to farm in the other states.

14. Growing gap between the elite and the impoverishedalso has its fair share on the nation's economic meltdown. Other factors are the erosion of human dignity, the erosion of dignity of life etc.

15. Other factors: these include ethno-religious crises, political instability, fraud, leadership crises, disease burden, budget priority and implementation etc.

\section{Impact Of The Economic Recession On Health}

Economic down turn and recession in the globe has affected people across the world in many ways. Health impacts of these recessional factors are the most severe ones especially, in an already stressed health care delivery system like ours. The overwhelming impact of the recession would undoubtedly result in increased rate of malnutrition anaemia, infant and maternal deaths, communicable and non communicable diseases, psychological disorder, social maladaptive behaviours, and violence to mention a few (Sowunmi 2009).

Currently 46 million Americans are without health care insurance and the number of Americans who are optingout of their current company's health insurance programme is also increasing (Louise, 2008). The consumer with health care coverage has decrease in spending for health care needs. Paying for health care appointments, prescriptive drugs and test related to prevention were declining (Furmans, 2008).

From the foregoing we can see that the impact of the Economic Recession on health is enormous and varied, we can therefore itemize them as follows:

1. Total health spending in countries that have been affected by an economic downturn tend to fall.

2. The cost of imported medicines, raw materials and medical equipment will increase. 
3. If the costincreases are not absorbed, the impact will reflected in shortages or increased cost of care.

4. Some Expenditures on medicines may be better protected than others. It is ethically difficult, for instance, to stop treatment with anti retroviral agents. Such a situation risks exacerbating the tension between HIV/AIDS treatments and other forms of health spending.

5. Falling remittances.

6. Reduction in household income due to job losses as Industries are likely to wind-down.

7. Reduced spending has impact on health and education, and ultimately on the well-being of families and the development of the community as a whole.

8. Utilization of health services:-decreasing health spending, increased cost of treatment, and reduced family income and/or assurance coverage will affect use of health services and their quality.

9. Health Outcomes:-A significant reduction in spending or life-saving intervention will increase mortality.

10. Shortages of food and consequent malnutrition predispose individuals to disease and thus, act in vicious concert with the economic downturn.

11. Official development assistance for health tends to fall during periods of recession, but this is not always the case.

\section{Implication to Nursing Education and Practice}

Nursing as a profession exits in response to the needs of the society and holds ideas related to mans health throughout his life span. Nurses direct their energies towards the promotion, maintenance and restoration of health, the prevention of illness, the alleviation of suffering and the insurance of peaceful death when life can no longer be sustained.

Neuman (1972) defined nursing as a unique profession in that it is concerned with holistic client care and all variables affecting an individual's response to stress. Furthermore, Deyoung (1982) views nursing 'as caring' and nurturing of the physical, social, spiritual, cultural and emotional wellbeing of individual, family or community'.

Nursing has gone through different evolutionary stages in its search for excellence from a technical service to a client-cantered care that emphasize the client, his right and basic needs as an individual and decision that evolve the client not only as a partner but also as an important member of the health team.

The current economic meltdown poses a challenge to this posture. Hence the need to examine the impact of this great economic downturn as it affects the profession and care.

\section{Impact on funding from Donor agencies}

Developing countries such as Nigeria receive a lot of support from developed nations such as the US, UK, Canada, Germany, Netherlands etc. These funds come from Foundation and philanthropy, Government Aid/subvention and corporate sector support.

These organization, governments and foundations are likely to supper due to unprecedented poor returns from investments and reduced donation. This may lead to drastic reduction or outright withdrawal of their sponsors of health development programmes. Some foundations such as The Gates Foundation and Mac Arthur Foundations have announced intention to withdraw their funding in 2009.

The effect will be dilapidated infrastructure in training schools, lack/inadequate supply of models and equipment; financial support for capacity building for the health workers, including nurses, may be withdrawn, training and updating the knowledge of nurses etc.

\section{Impact on the Universities}

The university system is one of the important global health complexes for human resource development. It is a foundation for research and human resources capacity building in developing countries through education and exchange programmes. With the current crisis the impact will be drastic reduction on endowment, classes cut and hiring of qualified staff freezes. Then there will be reduction in the number of graduates produced, worsening the already shortage of workforce. Research will slow down, negatively affecting new development and interventions necessary for capacity building in nursing.

\section{Impact on Human Resource Development}

Government sponsorship of nurses and midwives for training and retraining is likely to be affected as this will drastically reduce due to inadequate budgeting provision and economic measures. Hence, impacting on human resource development. This is because nurses and midwives may not have the opportunity to attend continuous professional development programmes and in-service courses. Other factors here include, poor career structures, working conditions and remuneration, uneven distribution of workers at different levels of service delivery, from national program officers to health facility personnel (these would possibly be taken care of by the recently approved Scheme of Service for Nurses). 


\section{Impact on the cost of Nursing Services}

The cost o nursing services will be affected, particularly, in privately owned hospitals that put the burden of their tax, running cost and possibly make profit on the poor client. In an attempt to escape this, the client patronizes the traditional healers, unqualified(quacks) personnel or ill-equipped private hospitals. The end result is that the client's case becomes complicated and in the final analysis pays for the management of the complications and also prolongs his stay in the hospital. Number of elective surgeries may fall.

\section{Impact on Nursing Research and Development}

Funding for nursing research has been poor or non-existent for a number of factors. With the recession ths position is further compounded. Community Based Organization (CBO) and Non-Governmental Organizations (NGO) etc, have announced plans or indicated reduced giving and leverage or may withdraw totally. This will have negative consequences, for research and development.

\section{Man power Shortage}

Shortage of nurses and midwives have been reported even before the crisis. Nurses and indeed other health workers are in poor supply, a ratio of 1:32(nursesto patients) is ridiculous if not suicidal. The shortage is only going to get worse as many nurses will be retiring in the next 5-10 years. The Midwives Service Scheme (MSS) where 3000 midwives were to be recruited is just going to touch the matter at the surface better still a mere political slogan.

\section{Working Conditions}

Closely connected to the shortage of nurses is impact on working conditions. Nurses will be over stretched with work load and stress. Thus exposing them to occupational hazards, lack of equipment and facilities, no insurance cover and stagnation on promotion and other incentives will not be forthcoming.

\section{Wage Freeze}

For four decades nurses in this country(Nigeria) have been agitating for a living wage but to no avail. Nurses at different levels of health care earn disproportionate salaries despite receiving same training and certification. The situation is worse in private health facilities. This will be further compounded by the economic recession. Wages are not competitive in the US.

\section{Unemployment}

An outrageous number of nurses retrenched between 2007-2009 have been reported in the US. To reduce running costs, preferences have been for specialized nurses for employment, hiring or part time nurses and firing experienced ones for newly qualified ones. Here in Nigeria, various names have been given viz: 'reforms', 'down sizing', 'right sizing' to retrench experienced hands and employ in-experienced 'loyalists' 'relations' etc. A combination of both a recession and the current trend will 'devastate' nursing wages and opportunities for employment.

\section{Impact on Schools of Nursing}

This is worst hit. Every facet of the training schools are in recession viz- obsolete teaching aids, book and facilities, dilapidated buildings; 'toothless' stooth forceps; outdated tutors, who are ill-trained and ill experienced; nonchalant, lazy and directionless students; non-autonomous schools; non-professional and lobbyist proprietors; detached, uncompromising and toothless council, a curriculum that is obsolete etc-paint the picture of our schools. The situation in a recession will better be imagined.

\section{National Health Insurance Scheme}

The health insurance scheme can be described as a social security in the health sector which guarantee the provision of health services to needy patients promptly on the payment of token contributions at regular intervals(premium) (Obembe,2000). The question is- Where is the guarantee? Who is to pay for whom? However, the scheme seems to be the only hope of the common man toward gaining access to adequate healthcare in Nigeria of tomorrow. It is still not all encompassing (some states are yet to implement). Where it has been implemented (federal establishment) 'out of stock syndrome' abound for 'supposedly' costly drugs. What is the future in a depressed economy? Also nurses not covered by the scheme may not be able to pay for decent health insurance.

\section{Drugs}

Adulterated, counterfeit and fake drugs are still in Nigeria. The implication for the Nurse is adverse reactions; patients prolong stay in hospital; and emotional and psychological trauma. It is no better in a recession. 


\section{Regulatory Bodies.}

Lack of or weak governance, regulatory bodies and reliable instruments to reinforce,, regulate, education and practice. The Nursing and Midwifery Council of Nigeria is a parastatal of the Federal Ministry of Health. As an MDA it is constraint by the subvention it gets from the government. Cost of conducting examination and carrying out its function as enshrine in the Act establishing it will be high. Anything affecting it is directly proportional to the maintenance of standard of nursing education and practice in Nigeria.

The National Association of Nigeria Nurses and Midwives though not a regulatory body, has the responsibility of ensuring standard of practice and taking care of the welfare of its members. Recessional constraints may likely not allow it to carry out these functions resulting in lack of educational empowerment, motivation and low morale for its members.

\section{National Health Policy and Strategy}

Unfavourable national health policies that do not enhance mobilization and strategic involvement of nurses in policy formulation and programme planning at all levels of service delivery is what is obtained. For instance, Primary Health Care is left to a less skilled and poorly educationally prepared group.

\section{Way Forward}

\section{A) Possible Economic Policy Measures to End Economic Recession in Nigeria.}

Given the high level of economic pain, policymakers need to pursue stimulus policies that work. Keynesians School has suggested measures of ending economic recession. The major measure which is to reduce tax rate and increase aggregate demand.(Emmanuel, 2016). We shall elaborate on this.

\section{Reduction in Tax Rate}

Government should reduce tax rates on individuals, small businesses and corporations by lowering the tax rates by at least 10 percentage points. The government instead of reducing tax rate to increase purchasing power, rather increased the tax rate killing so many small scale business who cannot meet up with the cost of doing business. Foreign investors will be encouraged with reduction in tax rate. This will increase inflow of dollar to Nigeria economy, and ultimately increase investment cum standard of living. And this will solve the problem of high exchange rate.

\section{Effective Spending}

Mere increase in government spending will not solve the problem of recession. It is strategic spending in are with high multiplier effect such as agriculture and manufacturing sector that increase aggregate demand. Nigeria needs to expand her export earnings and production base through wise investment. Otherwise might likely end up in a classical Malthusian istuation, where the resource cannot support the population.

Injecting more funds into the economy is not bad, but there is need for diversification, allowing free flow of naira and stabilizing the oil sector, modernizing agricultural sector.

\section{Enhance access to credit}

Consumer access to credit will speed up the economy. The CBN recently raised the real interest rate of Nigeria. This policy should be evaluated. The maximum interest rate at $26.93 \%$ is too high. For instance, total consumer credit in Nigeria stands at less than $\$ 10$ billion in about $\$ 500$ billion economy, this corresponds to about $2 \%$ of her GDP. Look at some developed economies, consumer credit ranges from about $20 \%$ (USA) to $50 \%$ of GDP (Brazil).

South Africa, Afria's largest economy by PPP has a consumer spending to GDP ratio of $66 \%$. Nigeria should aim for a consumer credit to GDP ratio of about $10 \%$ over the next 5 years. This would be equivalent of injecting a stimulus of $\$ 50$ billion per year into the economy.

\section{Increase Expenditure on Skills}

Nigeria government should increase her expenditure on skills. This is one point that most African countries had always neglected. It is only skills that lead to production. People are looking for problem solver. So government should invest in skills acquisition in IT, telecommunications, agro allied, sports among others. The training should be $80 \%$ practical. There is need for multiple competences, particularly among youths as a measure to curb increasing global joblessness.

The greatest challenge today in Nigeria is unemployment. The government should partner with private organisations to organise entrepreneurship and skill acquisition programme. There should be high level of transparency in the programme to ensure the best candidates are picked. This way Nigeria will soon see herself on top of the fastest growing economy in Africa. 


\section{Increase Agricultural Produce and Export}

In the 1960s, agriculture was the main base of Nigeria, in terms of GDP, foreign exchange earnings and employment. Today, Nigeria spends about $\$ 10$ billion a year on the importation of agricultural products.

Nigeria government led by Buhari should stop talking and start working. Enough of talk, people want to see actions. The youth like earlier stated should be encouraged to go into farming. They should be trained free on various agricultural sectors.

There are lands lying fallow, the government should start farming on those lands. This will take Nigeria to the real position of giant of Africa.

\section{Increase manufacturing produce and export}

SanusiLamido (2016) during the economic submit on 'The Search For A New Growth Model.' noted that Nigeria should learn from country like Ethiopia and MelesZenawi, the late Prime Minister.

Ethiopia keeps growing years after years at $11-12$ percent. And what did Meles do?

'Like Nigeria Ethiopia is facing insecurities; yet took advantage of her resources. For instance, coffee originated from Ethiopia in the world. But, Ethiopian farmers, before Meles, would get 10 percent of the value of coffee from their crops'.

The Ethiopia would just produce the coffee and sell to companies, and the companies will take their coffee into Latin America and have it improved and dried and packaged. And Zenawi just asked: 'why can't we produce coffee in Ethiopia that would go straight from Ethiopia to the coffee shops in Europe?' (Noiko, 2016).

\section{B) Action Point For Health}

Attempts have been made to reduce the burden of funding on the population by initiating free material and child health service, national health insurance scheme, social health protection model, voucher schemes, health cards, exemption, and private health insurance and of recent the Sustainable Development Goals (SDG). Still, a lot is left to be desired as it requires a more comprehensive approach.

It is the candid opinion of this writer that the following suggestions will be useful in salvaging the situation for health and nursing;

- Evolve strategies that will diversify our national economy, increase production and improve internally generated revenue (IGR). Resolve the Niger -Delta crisis to further boost oil production.

- Nurse leaders must be prepared to speak out-unequivocally and on the basis of sound evidence- to make a case for nursing at times of crisis and always.

- Take appropriate actions it change or improve or broaden existing nursing curricular and raising the level of profession education. Especially, review the curriculum of the undergraduate to provide a period of internship if not in place.

- Policies for the health sector.

Primary health care provides an overaching approach to health care policy at a time of financial crisis. Need to review PHC entirely and come up with a blueprint for action. It continuing relevance lies in its value base, involvement, of nurses in policy formulation, implementation and evaluation. Providing of funds using common basket approach. (joint account) by all actors involved in health care financing in Nigeria. Expanding the NHIS coverage, implement a community based insurance scheme etc.

- Protecting health spending by making health spending more effective and efficient such as strict compliance to budget, increasing allocation to health at all levels etc.

- Training of Nurses: the hospital base training should continue concurrently with the University programme as is obtained in USA, Canada and Britain. Or at least a stopgap is created in the transition (reform) from the hospital based to the University.

- Clearly defined career structure: clearly defined structure is urgently needed in nursing profession to give a clear direction to professional nurses. A diploma graduate will know the entry point and the terminal point so as also for University graduates. The hierarchical order is emphasized. This can be achieved through the WACN by becoming a fellow and a well articulated scheme of service.

- Devise new ways of doing business in institutional health with a view to reducing overlap and duplications between the works of different agencies How to promote greater synergy between individual health programmes etc.

\section{Summary/Conclusion}

There is a direct relationship between economy and health and by implication the nursing profession. The present economic recession poses a huge threat as its end is not certain.

A global view of the recession reveals that the previous recession in the 1980 and 1990 started in the developing nations, but the current one started in the industrialized states, therefore, it is possible that the full effect are yet to manifest in the developing nations (WHO 2009). At the same time, for the many low-income 
countries that have been facing chronic financing mortgages, hardship is not now. The premise is that the health care crisis and the financial crisis will intensify from both the supply and demand sides of the equation. Those who argue that we mortgaging out tomorrow miss the point that if Nigeria can't survive today, there may be no tomorrow. Nigeria is currently in A \& E and need Emergency treatment from its health carers!

The government must have the final say. They should be able to take certain decisions and live with the consequences, not panicking because of pressure from opposition politicians and non-altruistic 'Economists and Professionals', who badger them into different policies without waiting for one to work only to come back and accse the government of not being 'inconsistent' and flip-flopping when those advice don't work.

In the longer term, the Nigerian economy needed to be restructured into a productive one rather than thee rent-economy it has been for the last 45 years or thereabout. The current pain is getting unbearable because this huge expanse of land (Nigeria's geographical space), and its 170 million people with high taste for foreign goods and services depended on a mono-productive sale to service all their needs. It was alright when the Oil prices soared to $\$ 100$ and above but that appetite and needs could never be sustained with a $\$ 50$ or less Oil price. Nigeria must among other things:

- Diversify the economy;

- Immediate reshaping of its entire shambolic infrastructural system;

- Rapid industrialization from within Nigeria;

- Development of its technology to a level where it can compete globally;

- Gradually restrict the export of pure primary products.

Nurses and health experts worry that by delaying care in the short term, patients will end up paying more in the long term if their health deteriorates. Deregulated health care will lead to deregulated health! Nurses and Midwives are the largest professional group in the health sector. We should set the pace to rescue the health of fellow Nigerians. Time for action is now. Yes we can!

\section{MERCI!}

\section{References}

[1]. BBC News (2016) Nigerian Economy Steps into Recession Business $31^{\text {st }}$ August 2016 http/www.bbc.com/news/business-37228741 accessed 15/11/2016

[2]. Central Bank Act to Calm Markets. The financial times September, 18, 2008.

[3]. Cooley, T (2008) Another Great Depression Stern on finance NYU Dept of finance

[4]. Choosudovsky, M (2008) Global Financial Meltdown global research Ca.

[5]. Christopher, M, Weed, M.A.T, MSN (2003) Evidence-based Treatment Explained Health Services Administration.

[6]. Chukwu, C.O.O.(2009) Sustainable Health Care Delivery in Nigeria: Prospects and Challenges. A paper presented et the Aual National Meeting of West African College of Nursing held in Abakaliki October, 2009.

[7]. Declaration of G20 Whitehouse gov.http//georgebush-whitehousearchievesgov/news/release/2008/u/2001-html

[8]. El-Yakub, K, (2010). The Global Economic Meltdown: impact on the Health Care Delivery in Nigeria.. A keynote address, at the three day sensitization and scientific seminar organized by NANNM in collaboration with West African College of Nursing (WACN) North East Zone.

[9]. Emmanuel, N (2016) Economic Recession in Nigeria: Cuses and Solution. Educalinfor.commhttp://edcacinfo.com/economic recession-nigeria/ accessed 15/11/2016

[10]. Evans-Pitchard, (a 2007-07-25) 'Dollar turn as huge credit crunch loans. Telegraph co.uk (telegraph mediamgroup limited).

[11]. Ehuemere, I.O. (2009) Human Resource Development: Impact of Present Global Realities. A paper presented at AGM and Scientific Conference of West African College of Nursing, Nigerian chapter held at Abakaliki, Ebonyi State Nigeria.

[12]. Fickler, M. (2008-10-23) Trouble Without Borders. The New York Times.http://www.nytimes.com(2008/10/24)bonusa//world business//24 won.html

[13]. Five Things Nigerians Need to Know About the Recession. Naij.com/http://www.naij.com/955575-5-essential-things-everynigerian-know-recession.htm/ accessed 15/11/2016.

[14]. Four Big Things that Led to Economic Recession. Naij.com http//www.naij.com/968918-4-big-mistakes-that-led-to-nigerianeconomic-recession.htm/ accessed 15/11/2016.

[15]. IMF World Economic Outlook April, 2009

[16]. Ishiekwere, T (2018) Worst Economic Crisis in 25 Years: What Nigeria Can Do To Get Out of Recession. Sahara Reporters $15^{\text {th }}$ November 2016.http://saharareporters.com/2016/10/05/worst-economic-crisis-25-yearswhat-nigeria-can-do-get-out-recessiontonyishiekwere. Accessed 15/11/2016.

[17]. Jacobs, N (2008)How Will Current Economic Meltdown Impact Healthcare:health hospital formerly ask the hospital pendust

[18]. Kale,A (2006) Research Methods in Nursing. $2^{\text {nd }}$ edition: Discovery House P. O Box 105, Maiduguri, Nigeria.

[19]. Kale, A (2009) The Role of Nursing Audit in Ensuring Quality Nursing Care: A paper presented on the occasion of the 2009 International Nurses Week Celebration organzed by NANNM Federal Medical Center, Nguru Unit Branch, YobeState , Nigeria.

[20]. Kale, A(2009) Evidence-Based Care:Primary Health Perspective. A paper presented at the 2009 International Nurses Week celebration organized by NANNM/ICN held at Abuja, Nigeria.

[21]. Naij.com V.P Osinbajo Speaks on Economic Recession in Nigeria http://www,naij.com/963339-economic-recession-just-mattertime-osinbajo-video-htm/. Accessed 15/11/2016.

[22]. NBS (2003)Poverty Profile of Nigeria, Federal Republic of Nigeria.

[23]. New Oxford English Dictionary1 (1998): Oxford University Press: USA.

[24]. Norm, Floyd (2008) 'United Panic'. The New York Times,http//normsblogs-nytimes/2000/10/24/unitedpanic

[25]. NPR 'The Giant Pool of Money' April 2009.

[26]. Obama -regulatory speech, June 17, 2009. 
[27]. Obembe, K (2000) Economy and Health Prospect of The National Health Insurance Scheme in Obembe- Ultrasound Guide to Obstetrics and Gynaeconogy in a Developing Economy. A personal experience in private practice Ibadan, Milmark publication, Ibadan.

[28]. Okolie, K (2009) Achievement of Millenium Development Goals (MDGS):A Challenge to Nursing Education and Practice in Nigeria. A paper presented at the Annual Conference for Heads of Nursing Education Programmes in Nigeria held at Choice Hotel Awka, Anambra State, Nigeria.

[29]. Osalor, P (2016) Nigerian Economic Recession and Entrepreneurial Revolution. Vanguard News $15^{\text {th }}$ November 2016. http://www.vanguardngr.com/2016/09/nigeria-economic-recession-entrepreneurial-revolution/ accessed 15/11/2016.

[30]. Oxford Dictionary of Economics(2002): Oxford University Press: New York.

[31]. Ote, H.U (2009) Keynote address delivered at the annual general meeting/scientific conference of the West African College of Nursing (WACN), Nigeria Chapter, Abakaliki, Ebonyi State.

[32]. Philippon, F (2008) Overview of the Crisis Stern on Finance NYU Stern School of Business Department of Finance.

[33]. Reuters (2009) Three Top Economics Agree 2009 Worst Financial Crisis Since Great Depression. Retrieved 2009-9-30 from Business World News database.

[34]. Sowunmi, O (2009) Keynote address delivered at the $13^{\text {th }}$ Annual Workshop of the Public Health Nursing Fepartment, University Collge Hospital, Ibadan.

[35]. Third World Network (2009) Economic Recession Structural Adjustment and Health TWN online.

[36]. WHO (2009) The Financial and Global Health, a report of a high level consultation Wrld Health Organization,Geneva.

[37]. Www,micrsoft.encarta(2008) accessed February 2010.

[38]. www.imf.org (2007) accessed February, 2010. 